\title{
Migration Infrastructure
}

Biao Xiang (Oxford University) and Johan Lindquist (Stockholm University)

\section{Abstract:}

Based on the authors' long-term field research on unskilled labor migration from China and Indonesia, this article establishes that more than ever before labor migration is intensively mediated by various actors. Migration infrastructure - the systematically interlinked technologies, institutions, and actors that facilitate and condition mobility — serves as a concept to unpack the process of mediation. Migration can be more clearly conceptualized through a focus on infrastructure rather than on state policies, the labor market, or migrant social networks alone. The article also points to a trend of "infrastructural involution", in which the interplays among different elements of migration infrastructure make it selfperpetuating and self-serving, and impedes rather than enhances people's migratory capability. This explains why labor migration has become both more accessible and more cumbersome. The notion of migration infrastructure calls for research that is less fixated on migration as behavior or migrants as the primary subject and more concerned with broader societal transformations. 
$\underline{\text { Introduction }}$

A puzzling development in many parts of Asia since the late 1990s is that international lowskilled labor migration has become both easier and more cumbersome. It has become easier in the sense that more people have gained access to legitimate overseas job opportunities, and that journeys are quicker and safer. It is more cumbersome as the social processes of migration have become more complicated with more non-migrant actors involved and more rules to navigate, which has often led to higher costs of migration. In China for instance, until the early 2000s only state-owned enterprise employees with government permission could work overseas legitimately. Today every citizen can do so, even those from remote hinterlands. At the same time, increasing numbers of intermediaries pushed up the average cost for working abroad in Japan, Singapore and South Korea - the top three choices for Chinese migrants - from zero in the early 1990s to 8000 US dollars by 2010, even as the net monthly wage of migrants remained stagnant at 500 dollars over the same period. ${ }^{1}$ While China had four recruitment companies that sent out 2,190 workers in 1979 (Zhang Gesheng 1999: 206), by 2010 it had about 3,000 licensed recruitment companies that dispatched about 600,000 workers a year. ${ }^{2}$ This represents a 60 per cent decrease of the number of workers sent out by each recruitment company. These figures would be even more striking if branch offices and unlicensed subagents were included.

In Indonesia a similar tendency is evident. Although wages have generally increased for migrants over time, fees to brokers, particularly informal recruiters of female domestic

\footnotetext{
${ }^{1}$ Xiang's primary data from fieldwork in northeast China and Singapore 2004-2008, 2011.

${ }^{2}$ The 3,000 recruitment companies included those licensed by the ministries of commerce, labor, transport (specializing in sea farers) and health (specializing in nurse migration). Companies licensed by the ministries of education and public security (for permanent emigration and general purpose border crossing) sometimes engaged in labor migration as well (estimate based on CHINCA, 2004-2012; Center for International Exchanges, Ministry of Labour and Social Security 2008; Xia Hong 2012:52). The Ministry of Commerce had 2,150 licensed companies who sent out 372,000 workers in 2007 (Chen Qinlan 2008: 32). From 2010 the Ministry of Commerce was designated as the single authority to oversee land-based labor outmigration, and has since cut down the number of licensed companies to below 1,000 in 2014.
} 
workers, have increased far more dramatically. ${ }^{3}$ Furthermore, the number of licensed recruitment companies and informal brokers has grown significantly since the 1997 Asian economic crisis. In 1995 there were less than 50 licensed recruitment companies that sent approximately 200,000 workers abroad each year, while by 2007500 recruitment companies were sending nearly 700,000 workers abroad annually, the vast majority of Malaysia and Saudi Arabia. ${ }^{4}$ In other words, licensed recruitment companies grew three times faster than migration.

More than ever before labor migration is intensively mediated. Consider Putri's journey from the island of Lombok, which in the past 15 years has become a major sending area for women migrants to Saudi Arabia. ${ }^{5}$ Divorced and in her mid-twenties, Putri is the primary caregiver for two young children. In 2009, Sari, a neighbor and successful migrant-turnedbroker, introduced Putri to her uncle, Pak Adi, an informal petugas lapangan, or "field agent," who recruits prospective migrants and delivers them to licensed recruitment companies. Pak Adi lives twenty kilometers from Putri near the island's main road and is a well-respected low-level bureaucrat in the regency capital. He and Sari courted Putri through home visits and frequent text messages, pointing out that she would not only make more than 200 US dollars per month as a domestic servant in Saudi Arabia, but also learn Arabic and perhaps even be invited by her employer to do the Umrah, the "minor pilgrimage" to Mecca, both accorded high status on predominantly Muslim Lombok. After Pak Adi gave her and her parents 100 dollars in "shopping money" (uang belanja) Putri was convinced and agreed to go to Saudi Arabia on a two-year contract.

\footnotetext{
${ }^{3}$ Lindquist's primary data from fieldwork in Lombok intermittently from 2007 until 2013. An informal labor broker in Indonesia can make up to 500 US dollars for the recruitment of each female domestic worker. ${ }^{4}$ The number of Indonesian migrants is from Hugo 2012: 399. The numbers of recruitment agencies is from unpublished data from the National Agency for the Placement and Protection of Indonesian Migrant Workers (BNP2TKI) in Jakarta.

${ }^{5}$ In 2011 East and Central Lombok were the Indonesia regencies with the second and fourth largest number of migrants departing during that year, respectively. See http://www.bnp2tki.go.id/statistik/statistikpenempatan/6779-penempatan-berdasar-daerah-asal-kotakabupaten-2010-2011.html, accessed June 23, 2014.
} 
With the process in motion, over the course of a month Putri was interviewed, registered, and examined as a prospective migrant. Sari helped her get a formal letter of permission from her parents and a so-called "family card" (Kartu Keluarga), both via the village head, while Pak Adi escorted her by motorcycle to the branch office of a Jakartabased recruitment company in Lombok's commercial center, Mataram, where she was interviewed and then medically examined, including a pregnancy test, at a registered clinic for migrants to Saudi Arabia. ${ }^{6}$ In the following weeks Pak Adi accompanied her to government offices on the regency level in East Lombok to get a birth certificate and identity card, before registering her at the office of the Department of Manpower (Dinas Tenaga Kerja), where she was interviewed by an official and given a letter of permission to make a special 24-page Indonesian migrant worker passport (paspor TKI).

After saying goodbye to her children and parents Putri was taken to live at the office of the local recruitment company. After a second pregnancy test she was given a contraceptive shot - pregnancy entails termination of the migration process at any stagebefore travelling to the recruitment companies' training center in Jakarta by airplane with Pak Adi and three other prospective migrants. Together with more than one hundred women she spent three months learning Arabic, and culturally specific forms of cooking, childcare, and general behavior. From Jakarta she was put on an airplane to Riyadh with around 50 other women. Upon arrival she was taken to a local labor agency and then to her employer, a family with three children.

Putri returned home two years later upon completion of her contract. The kafala, or sponsorship system, which links migrants to a specific employer in Saudi Arabia and other Gulf States, strictly limited her mobility according to her employer's preferences, who also

\footnotetext{
${ }^{6}$ These clinics are approved by the Gulf Cooperation Council Approved Medical Centres Assocation (GAMCA) in collaboration with the Department of Health in the sending country. For a critical commentary on GAMCA, see: http://www.migrant-rights.org/research/gamca-controversy-update/, accessed June 25, 2014.
} 
kept her passport from arrival until she was checked in for the flight home. ${ }^{7}$ Upon landing in Jakarta, Putri was diverted to a special migrant terminal designated for returning female unskilled workers. There she was interviewed and registered by government officials and her migration experience assessed by the International Organization for Migration's countertrafficking unit. Even though she was classified as a "migrant without problems," she was not allowed to leave the terminal on her own and was compelled to purchase a special bus ticket back to her home village.

Putri is escorted and encapsulated from the beginning until the end of the migration circuit. In fact, it is clear from the account that we cannot understand how she moves unless we examine how she is moved by others, including brokers, bureaucrats, transport companies, medical clinics, and international organizations. Furthermore, her mobility is conditioned by the transfer of documents, data, and money between actors. In this process money flows from the Saudi employer, to the Saudi labor agent, to the Indonesian recruitment company in Jakarta, to the branch office on Lombok, and to the Pak Adi, the "field agent," who distributes money to Sari and Putri, and to bureaucrats from the village level and up, in order to set the process of migration in motion. Upon return, Putri carried two years of salary, nearly 3000 US dollars, and beyond some minor extortion at the Jakarta airport and on the road, she was able to reach home with nearly the sum total.

"It is by mistake, or unfairness," Bruno Latour writes, "that our headlines read 'Man flies,' 'Woman goes into space.' Flying is a property of the whole association of entities that includes airports and planes, launch pads and ticket counters. B-52s do not fly, the U.S. Air Force flies" (Latour 1999: 182). If it has always been epistemologically problematic to assume that migrants migrate, as opposed to constellations of migrants and non-migrants, of human as well as non-human actors, this is even more so the case today. The notion of

\footnotetext{
${ }^{7}$ For more on the kafala system, see Gardner's (2010) work on Bahrain.
} 
"migration infrastructure"- the systematically interlinked technologies, institutions, and actors that facilitate and condition mobility_opens up such spaces of mediation to analysis. In broad terms, we stipulate five basic dimensions of migration infrastructure: the commercial (recruitment intermediaries), the regulatory (state apparatus and procedures for documentation, licensing, training and other purposes), the technological (communication and transport), the humanitarian (NGOs and international organizations), and the social (migrant networks). ${ }^{8}$ As infrastructure is ecological and relational (Star 1999), and thus a socio-technical constellation (see also Larkin 2013), these five dimensions are deeply entangled and must be considered in cultural and historical context. In relation to unskilled international migration from China and Indonesia, this has led to a process of "infrastructural involution" in which migration infrastructure has become self-perpetuating and self-serving and come to impede rather than enhance people's migratory capability. It is in this process that we can understand the paradox of increasing levels of both freedom and complication. ${ }^{9}$

While it is this common process of involution that has inspired us to develop the concept of migration infrastructure, China and Indonesia's different trajectories make them productive cases for comparison. Spontaneous migration from the People's Republic of China did not resume until the 1980s, and the development of outmigration has since been a process of measured liberalization in which increasing mobility is encouraged but subject to nuanced regulation. In contrast, migration from Indonesia, especially to Malaysia, has a long tradition. The main change in recent times, especially since 1997, has been a process of formalization, as spontaneous and generally undocumented mobility has been incorporated into government designated migration channels.

\footnotetext{
${ }^{8}$ Larkin (2013) points out that any discussion of infrastructure is a categorical act since the embedded nature of infrastructure means that it is difficult to mark a beginning or an end to its existence.

${ }^{9}$ A report by International Labour Organization (2006) pointed out this phenomenon in Asia, but primarily attributed it to commercial intermediaries.
} 
The two countries also differ in the manifestation of various dimensions of migration infrastructure. Labor migration from China is dominated by male construction and manufacturing workers to East Asian countries. ${ }^{10}$ In contrast, in 2006 about 80 percent of Indonesian documented migrants were women, 88 percent of whom were domestic workers (Hernández-Coss et al. 2008: 8), ${ }^{11}$ which is a part of a broader femininization of labor migration from Asia (Goss and Lindquist 2000: 396-397). The gender difference between the two cases should not taken as given, but is part of the evolution of migration infrastructure. The widespread networks and shared religion between predominantly Muslim Indonesia and Malaysia and the Middle East have made Indonesian women desirable domestic workers, as social infrastructure has developed into recruitment business, which in turn has become a site of regulation. China's isolation after 1949 dismantled similar transnational social infrastructures, while outmigration during the reform period has been closely tied to state-led projects that usually depend on male labor. Furthermore the government disallowed Chinese women to work as domestic maids in Singapore, Hong Kong, Taiwan and Macau with shared cultural backgrounds, fearing that social sensitivities associated with domestic workers in the destination country could complicate the management of other types of migration or even bilateral relations. ${ }^{12}$ The fact that Chinese migrants need to finance their migration project upfront also discouraged women, who still wield much less power than in in making financial

\footnotetext{
${ }^{10}$ No national statistics are available concerning the gender composition of labor migration from China, but internal reports from the Ministry of Labor indicate that women make up less than 30 percent of the sum total (Ministry of Labor and Social Security 2005; Bureau of Labor and Social Security, Liaoning province. 2005). In terms of occupation, an average of 40 percent of Chinese migrants worked in manufacturing industries (especially textiles and food processing), with 25 percent in construction and 15 percent in agriculture, forestry, and fishing industries. Less than 0.5 percent of migrants had white collar-jobs between 1995 and 2013. In terms of destination, Asia and Africa account for about 90 percent (CHICA Annual Reports 2004-2012, Zhang Gesheng 1999, Yin Hao 2009).

${ }^{11}$ By 2011, the number of female migrants had dropped to around 65 percent, which is largely an effect of the current moratorium on sending domestic workers to Saudi Arabia as well the aftereffects of an earlier moratorium to Malaysia. It is very likely that the proportion of female migrants will rise again. See http://www.bnp2tki.go.id/statistik/statistik-penempatan/6758-penempatan-berdasarkan-jenis-kelamin-20062012.html, accessed on June 25, 2014.

${ }^{12}$ Interview by Xiang with a department director of the Ministry of Commerce, April 23, 2007, Beijing. In addition to the ban imposed by Beijing, Singapore and Taiwan do not grant visas to domestic worker migrants from mainland China.
} 
decision, especially in rural areas. In contrast women migrants from Indonesia go into debt and have their salaries deducted abroad (Lindquist 2010a).

This article does not aim to provide a comprehensive overview about the aggregate patterns of migration as observed from afar. Instead it focuses on the internal dynamics of migration infrastructure and delves into the practices of multiple actors in the actual process of migration. In doing so we rely on our primary, ethnographic data gained from long-term field research in northeast China (a total of eleven months between 2004 and 2008, and 2011) and on Lombok, Indonesia (eight months between 2007 and 2014). We conducted in-depth interviews and participant observation, primarily with commercial recruiters, in sending as well as receiving countries, namely Japan, South Korea (on Chinese migrants), Malaysia (on Indonesians), and Singapore (on both). Approximately 400 informants were interviewed in total. Unless stated otherwise, all information is drawn from the author's primary field research. In the following sections we will first discuss what migration infrastructure does as a concept to migration studies, and what migration infrastructures do in reality as operational systems. We will then demonstrate how infrastructural involution shapes labor migration from China and Indonesia, and as such can serve as an explanatory tool. Finally, we conclude by offering more general remarks while suggesting directions for further research.

\section{What Does Migration Infrastructure Do?}

It is not entirely new to conceptualize migration as a social process that organizes and channels mobility rather than in terms of mobility per se. Migration cannot "be described without attention to the necessary spatial, infrastructural moorings that configure and enable mobilities" (Hannam, Sheller, and Urry 2006). But how is "migration infrastructure" different from "migration system"? What can we gain by re-conceptualizing, migration industry as 
commercial infrastructure, migration apparatus as regulatory infrastructure, NGOs and international organizations in terms of humanitarian infrastructure, and finally migrant networks as social infrastructure?

Migration systems theory approaches migration as part of two-way flows of people, goods, and ideas between particular places, and stresses that migration will change the conditions of the sending and receiving places and the connections between them, thus altering the migration flow itself (Mabogunje 1970). But migration does not always form a "system." The tendency to reify "system" impedes proper appreciation of the diverse and sometimes unstable patterns of migration, and thus explains why the theory has not progressed far since the early 1990s (see King 2002). ${ }^{13}$ Migration infrastructure draws inspiration from the processual perspective that conceptualizes migration as multi-directional and self-adjusting movements, but shifts focus away from how migration behavior becomes stabilized to how migration is mediated. Migration flows can be fragmented and short-lived, but infrastructure retains a particular stability and coherence. In other words, we are interested in the internal constitution and modular components that mediate migration rather than a bounded system.

"It is not people who migrate but networks" (Tilly 1990: 79). The migrant network has been widely regarded as the single most useful variable in migration studies (e.g. Massey 1990, Arango 2004, Gold 2005). Instead of describing how migration becomes selfsustaining through networks, migration infrastructure inverts this perspective and seeks to examine how networks have infrastructural effects. Hamashita's (e.g. 2008) historical research provides an example of the infrastructural approach. Migrant networks between China and Southeast Asia have formed the basis of the China-centric East Asian system since the sixteenth century. These networks sustained cross-region exchanges when China was

\footnotetext{
${ }^{13}$ This theory was later developed into a macro-mapping device that sought to discern how international migration becomes spatially clustered due to historical (e.g. colonial legacies) and geographical reasons (Kritz et al. 1992).
} 
itself in turmoil, were adapted by European powers for their colonial agendas, and in turn served as a counterforce resisting colonial penetration. Networks are thus modular and can be copied, extended and adapted, yet need to be enacted in interactions with other social forces. It is by examining these infrastructural properties that we can productively explore the explanatory power of migrant networks, or what we call social infrastructure.

The notion of "migration industry" calls attention to the services that facilitate migration rather than the migrants themselves (Hernández-Léon 2008: 154). The recent effort to broaden the scope of the migration industry by including actors who "control" and “rescue" migrants (e.g. Agustin 2008; Gammeltoft-Hansen and Sørensen 2012; see also Anderson 2014) brings the concept even closer to migration infrastructure. But migration industry constructs migration as a particular form of economy that neglects important regulatory, social, and technological dimensions. ${ }^{14}$ Migration brokers are not simply selling opportunities for migrating overseas, they are also dealing with various components of infrastructure — such as collecting documents, organizing medical tests, or dealing with predeparture training — which are increasingly an important part of their business, but which also have far-reaching regulatory effects. Furthermore, brokers not only bridge the existing demand for migration and supply of jobs. The demand for migration, as we see in Putri's case, is often actively cultivated. In China, the increasing costs, the stagnant migrants' wages, and the strict age limit set by employers (e.g. most workers need to be younger than 35 according to most employers in Asian countries) have compelled brokers to mobilize workers in the poor and remote countryside. At the same time brokers help arrange loans to finance the migration, for instance by tapping on the poverty alleviation fund of the local government in China. This is much more than a service business.

\footnotetext{
14 The same point may be made of "migrant institution," which Goss and Lindquist (1995) developed as a middle-range concept preferable to household or social network, using Anthony Giddens' theory of structuration.
} 
Regulatory infrastructure is closely related to "migration apparatus," which Feldman (2012: 6) defines as the disparate institutions, policies and discourses that turn migration into subject of governance, or a "static policy object." Like the notion of apparatus, migration infrastructure emphasizes operational processes rather than end-oriented intentions. But unlike apparatus, which focuses on governmental operations and policy-makers, infrastructure includes a broader array of actors. The standard delegation of visa processing to private agencies, the outsourcing of migration control to civilians and employers as in the kafala system, and, in the context of deportation, the increasing involvement of contractual relations between states, on the one hand, and the International Organization for Migration (IOM) or private "security companies," on other (Xiang 2013), all testify to the increasing importance of non-governmental actors in the regulation of migration. Regulatory infrastructure - particularly reliable data registration systems — is also deemed important for the purpose of protecting migrants' rights, as the illegal and undocumented is unadministerable and thus unprotectable (Global Commission of International Migration 2005).

This leads to humanitarian infrastructure, which consist of mass media, states, international organizations, and NGOs — including those set up by migrants themselves - that are related to one another in practice through funding circuits and transnational advocacy networks (Keck and Sikkink 1998), and more generally through the circulation of human rights norms and images and discourses of suffering (McLagan 2003, Lindquist 2010b). ${ }^{15}$ The importance of mass media in generating broad responses to abuses against migrants is increasingly obvious. While humanitarian programs are generally treated separately from,

\footnotetext{
${ }^{15}$ Although humanitarianism and human rights follow from two different lineages and landmark events - the founding of the Red Cross and the Universal Declaration of Human Rights following World War II, respectively (Bornstein and Redfield 2011: 5-6) — both seek to improve the human condition and have in many ways come to reinforce one another in recent decades, particularly with the rise of NGOs. Counter-trafficking and human rights protection have emerged as the two pillars of migration-related humanitarian infrastructure in recent decades.
} 
and often as antagonistic to, government and commercial actors, in reality NGOs have come to shape migration through active policy interventions and public advocacy and are critical to the transnational humanitarian infrastructure that is central to the post-Cold War global order in which human rights and biopolitics take precedence over national sovereignty (Hardt and Negeri 2000: 313-4). The close alliance between the United States government and NGOs worldwide in the struggle against human trafficking is a case in point, as is the 2006 End Human Trafficking Now campaign in which the ManpowerGroup, one of the largest global human resource recruitment companies, was the first signatory of the Athens Ethical Principles. Ironically, international pressure for rights protections directly encouraged the development of a migration industry in China. Until the middle of the 1990s employers in the Middle East covered all the costs including recruitment fees for migrants, which was then deducted from the migrant's salary upon arrival. When wage deduction was condemned as a human rights violation, migrants had to pay all costs prior to departure, which allowed Chinabased brokers to increase their demands.

Perhaps the most obvious element of migration infrastructure is the technological. ${ }^{16}$ Most notably, ICT (information and communications technology) has not only revolutionized communication between migrants, ${ }^{17}$ but also come to facilitate the recruitment of migrants, as in the case of Putri. It should thus not be taken for granted that ICT necessarily empowers migrants. Furthermore, the deregulation of airline industry in Asia has significantly altered the transport of unskilled migrants. The development of regulatory infrastructure, for instance the externalization of border control, is also to a great extent reliant on new technologies. The dramatic growth of biometric identifiers, systems of data storage, and the exchange of this data on an international scale, points to the rise of regulatory infrastructures that both aim to

\footnotetext{
${ }^{16}$ For an impressive account of the impacts of technological infrastructural developments on human mobilities, see Urry 2007.

${ }^{17}$ For an example on the importance of communication technologies in the context of relationships Filipino migrant mothers and their children who remain behind, see Madianou and Miller 2012.
} 
facilitate mobility and intensify control, even if their actual effects on migrants must be carefully considered in context (Lyon 2008). It is thus by interacting with other components that technological infrastructure becomes particularly consequential.

Each of the five dimensions of migration infrastructure must be considered together. This perspective is not meant to be comprehensive - this would be the least of our desiresbut rather to foreground intersectionality as an operational logic of how migration is actually constituted. We are thus less concerned with the external contour of migration and migration infrastructure - identifying where its beginning and end - than with the internal workings. The primary value of the concept lies with its sharpness, not its breadth. In contrast to the feminist concept of intersectionality (e.g. Crenshaw 1991), which considers the effects of intersections between systems of power on the lives of women, our foregrounding of intersectionality allows us to identify particular sites of concern that are focused on migration but not necessarily on the migrant per se. As Larkin (2013: 338) has pointed out, from this perspective identifying a methodological approach to migration infrastructure is also a theoretical problem. In other words, migration infrastructure allows for multiple approaches and perspectives.

\section{$\underline{\text { Infrastructural Involution }}$}

Over the last two decades, in the labor migration infrastructure in China and Indonesia, the growth of one dimension has led to the growth another, especially between the regulatory and the commercial, creating a self-reinforcing mechanism. Furthermore, the growth of regulatory and commercial infrastructure has been primarily intensive (e.g. by introducing increasingly detailed medical examinations and specialized training of would-be migrants) rather than extensive (enlarging the population base of migrants or broadening the scope of 
destinations), though the two trends are not necessarily mutually exclusive. ${ }^{18}$ The

intensification of migration infrastructure has not generated new capacities for migration. We

call this infrastructural involution. ${ }^{19}$

China: regulation through liberalization

Migration infrastructures hardly existed in China when outmigration started as part of state-organized overseas projects at the end of the 1970s. Throughout the 1980s the government selected workers from state-owned work units to dispatch overseas. In practice some government departments and work units charged the workers money for sending them overseas. The problems became obvious in the late 1990s: inefficiency, nepotism, corruption, and illegal emigration. ${ }^{20}$

To address these problems, the policy consensus in the 1990s was that migration must be made freer. Nearly twenty administrative procedures in passport application were cut out, and by 2005 most urban residents were able to apply for a passport by presenting their identity cards. The Passport Law, effective from January 2007, enshrined every citizen's legal entitlement to possess a passport. In 2002 private companies were allowed to engage

\footnotetext{
${ }^{18}$ As an example of the intensification, pre-departure training has become increasingly common for unskilled migrants, particularly women, which takes up time, money and labor (for the Philippines, see Rodriguez (2010, chapter 2), for Indonesia, see Killias (2012, chapter 4), for Sri Lanka, see Frantz (2011, chapter 3)). The limit of the expansive trend can be illustrated by the scope of destination. In the case of Indonesia, Malaysia and Saudi Arabia predominate since the 1980s; in the case of China, Asia accounts for more than 70 percent of all unskilled labor migrants since the mid-1990s, and the top desintations remain unchanged.

${ }^{19}$ Clifford Geertz, who popularized the concept of involution in social sciences, defined it as "the overdriving of an established form in such a way that it becomes rigid through an inward elaboration of detail" (1963: 82). In the case of agricultural involution, increasing population pressure with unchanged amount of resources and levels of technology forced peasants to increase labor intensity. Labor intensification increased total production, but not per capita output, thus leading to stagnation and poverty (see also Huang 1985). Prasenjit Duara (1987; 1988) developed the concept of state involution in his analysis of the building of the modern Chinese state after the collapse of the Qing dynasty before the establishment of the People's Republic. Unable to increasing its administrative efficiency and its ability of social mobilization, the modernizing state relied on political brokerage to extract additional resources, which reproduced the imperial state-society relation instead of creating a new one. Most importantly, the efforts of resource extraction turned the previously communityoriented "protective brokerage" to self-interested "entrepreneurial brokerage"; the state became both increasingly dependent on these informal structures while losing control over them (Duara 1987: 132-3). ${ }^{20}$ In the late 1980s a large state-owned company set up by offspring of senior party cadres was known among political and business elite as the "leading human smuggler." Xiang interview with a former staff of the company, 23 July 2007, Shenyang.
} 
with labor exports, and public and government institutions were banned from the business in order to maintain the integrity of both the market and regulation. The annual outflow of labor migrants increased from 253,000 in 2000 (CHICA 2004:10) to 527,000 in 2013 (Ministry of Commerce 2014), though the increase was much slower than that of high-skilled especially student emigration. This is partly because the migration infrastructure for skilled migration is much simpler and has not led to involution. ${ }^{21}$

Liberalization removed the state from direct control over recruitment, but enhanced its overall regulatory capacity. The previous system of passport application, for example, required every citizen to obtain political approval from the work unit or local government officials, thus putting everyone under strict scrutiny, but in a decentralized and scattered manner. The procedural simplification effectively centralized regulation. Decisions are now made according to a single set of criteria instead of subjective assessment, and data is administered in unified manner. This was made possible through the establishment of a nationwide computer data system of identification and especially criminal clearance, which constitutes a critical part of regulatory infrastructure. With regard to recruitment companies, the government set a high bar for issuing licenses. Companies had to pay a minimum of 60,000 US dollars to a designated bank account as security, hire staff with work experience in international relations and career development, and appoint their legal representatives overseas.

The regulatory and the commercial infrastructure had so far expanded hands in hands, namely the government developed regulatory infrastructure while at the same time requiring commercial companies to strengthen managerial capacity. Government consciously

\footnotetext{
${ }^{21}$ The number student emigrated from China increased from 39,000 to 413,000 between 2000 and 2013 (Education Online 2014). Overseas education agencies (452 licensed by the Ministry of Education as of November 2012) play an important role, but the social process of student migration is less meticulously regulated and is much more straightforward than that of unskilled labor.
} 
attempted to govern migration through commercial infrastructure, turning companies literally into its arms. This collaborative co-evolution, however, soon developed into an "arms race," in which the regulatory and commercial infrastructure competed to outpace each other in order to ensure their respective core interest: order for the former and profit for the latter.

The arms race started with the emergence of hierarchically linked chains of recruitment as the central form of commercial infrastructure. Large companies in major cities served as "windows" to the international market by signing contracts with foreign firms and process paperwork. At the bottom were local institutes or individuals in districts or rural townships, referred to colloquially as "the legs". The relations between the window and the legs were often mediated by middle-level brokers in prefectures due to the long physical distance between the two and more importantly because of the complexity of procedures. Middle-level brokers produced files of the migrants by collecting and authenticating documents, organizing medical checksups, filling out forms, and having photos taken. Would-be migrants relied on legs because they did not trust strangers, especially when large amounts of money were involved. Through such chains, windows profited from their monopoly over licenses while delegating the task of recruitment to other intermediaries, who took cuts along the way, thus pushing up costs. What concerned the government most, however, were that recruitment chains increased disputes both in China and overseas, either due to inadequate coordination among brokers or deliberate misinformation by some brokers in the chain.

Believing that there were too many unqualified brokers and that the recruitment procedure was too loosely regulated, the government, particularly the Ministry and Labor and Ministry of Commerce, responded in a number of ways from 2005. First, the criteria for licensing was tightened. The required minimum security deposit was raised over the years from 80,000 US dollars in 2002 (Minister of Labor and Social Security et al 2002) to 500,000 in 2012 (State Council 2012). Second, the provincial government was tasked to develop 
elaborate mechanisms, including data reporting systems, approval procedures, and regular meetings, to monitor the companies' recruitment procedures. Third, and most importantly, window companies were held responsible for disputes and were punishable, including being delicensed, for irregularities in the recruitment process that took place in their names.

This unintentionally complicated the commercial infrastructure. It further reinforced the monopoly position of the windows because it made more difficult for small companies without required financial layout and professional staff, let alone the legs, to obtained licenses. Furthermore, the windows passed liability downward and held the lower levels of brokers responsible in case of disputes overseas. Some legs charged migrants a bond (3,200 4,800 US dollars) before departure, which was refunded only upon return to China at the end of their contracts and without violating any rules. In some cases windows and legs worked together to introduce the disciplinary method of lianzuo, or "linked seats," that collectively punished groups of migrants — who may previously not have known each other-because of the misbehavior of one of them. For enforcement, the brokers would have to work with local government. Thus both migrants' social networks and local regulatory infrastructure were turned into disciplinary devices of commercial brokers.

In 2010 the Ministry of Commerce launched a campaign to set up "labor service platforms" at the county level, and by the end of 2012, there were 168 such platforms across the country (Wen Yue 2013: 9). The platforms are networks of government departments coordinated by a specially created government agency, which have direct access to labor force and to window companies, and are thus able to process the entire recruitment procedure. In other words, it aims to create a new, flat regulatory infrastructure to reconfigure the multi-layered commercial infrastructure. The outcome of this reform remains to be seen, but it is clear that the interplay between the commercial and regulatory infrastructure has been the central thrust of the change. 


\section{Indonesia: formalization and incorporation}

Prior to the 1980s international migration from Indonesia was largely organized through social and commercial infrastructures, namely migrant networks and commercial brokers. Migration to neighbouring Malaysia, in particular, has deep historical roots and was largely male and undocumented, based on patchwork networks of transportation and temporary housing by which migrants were moved across the country and national borders, but more importantly, by the tai kong, or smugglers, who controlled the migration process and social infrastructures (Spaan 1994, Jones 2000). International documented migration became an explicit dimension of national development with the rise of largely female migration to the Middle Eastern oil economies during the 1980s, as both commercial and regulatory infrastructures expanded, notably with the expansion of regulations in response to the growth of private recruitment agencies, and the creation of the Centre of Overseas Employment (Pusat AKAN) within the Department of Manpower in 1984 (Spaan 1999: 1589).

The years following the 1997 Asian economic crisis were a watershed, as the collapse of the Indonesian rupiah led to the increase of both the number and proportion of documented migrants. ${ }^{22}$ In particular, the rise of the Malaysian deportation regime led many to turn to more secure forms of migration. Furthermore, the liberalization of the economy after the fall of Suharto led to a dramatic growth in labor recruitment companies along with an expanding but increasingly efficient migration bureaucracy. Finally, the highly publicized mass deportations, recurring abuses against female domestic workers abroad, and the widely acknowledged extortion of returning migrants - all in the context of an increasingingly vibrant civil society—led to an intensifying focus on the "protection" (perlindungan) of

\footnotetext{
${ }^{22}$ See Hugo (2012: 399) for the increase in documented migration. There is no data on the drop in undocumented migration, but on-going fieldwork in migrant-sending areas, in tandem with Malaysian deportation programs point to a significant drop in undocumented migration (e.g. Chin 2008; Lindquist 2010a).
} 
migrants. For instance, as in the case of Putri, a specified migrant reception terminal at Jakarta international airport opened in August 1999 (Silvey 2007).

In the past decade these infrastructural developments have intensified. In 2006, the National Agency for the Placement and Protection of Indonesian Migrant Workers (Badan Nasional Penempatan dan Perlindungan Tenaga Kerja Indonesia, BNP2TKI), was created to coordinate government activities, both on the national and provincial levels, thus further expanding the regulatory infrastructure, and as of 2013 there were 546 licensed recruitment companies with approximately 4000 branch offices around the country, as well as an inestimable number of "field agents" such as Pak Adi, who handle the actual recruitment of migrants. ${ }^{23}$ Each recruitment company must pay a 50,000 US dollar cash bond for licensing and is bound to specific procedures, for instance, a strict process of documentation and compulsory pre-departure training, which increasingly has come to integrate commercial and regulatory infrastructures, not least on the provincial level where most recruitment takes place. Processes of delicensing have also become increasingly common.

BNP2TKI's contradictory role in both promoting migration and protecting migrants suggests - as noted above - that the expansion of a gendered humanitarian infrastructure should be understood in relation to, rather than in contrast to, commercial and regulatory infrastructures (cf. Rudnyckjy 2004), ${ }^{24}$ particularly with regard to the significant profits for the recruitment of female domestic servants. The differential treatment of men and women is evident in the context of regulation; for instance, there are higher minimum ages for women who work as domestic servants than for men, and intermittent moratoriums to sending countries such as Malaysia and Saudi Arabia focus exclusively on domestic workers. The

\footnotetext{
${ }^{23}$ Lindquist interview with office manager at the head office of APJATI, the Indonesian Manpower Services Association (Asosiasi Jasa Tenaga Kerja Indonesia), in Jakarta, June 4, 2014. Of the 546 licensed companies, 461 were members of APJATI, and these had a total of 3,227 licensed branch offices.

24 The Philippine Overseas Employment Administration, founded in 1982, was also created with a similar dual function (Goss and Lindquist 2000: 396).
} 
concern with "protection," which is written into government directives, ${ }^{25}$ offers an obvious link to the rise of the NGO sector after the fall of Suharto. Most notably, the increasing concern with human trafficking has to an even greater degree created a focus on women. The IOM, for instance, has a counter-trafficking office at the migrant reception terminal at the Jakarta airport. More generally, reception terminals have been opened at other airports across the country. In similar terms, a reception and return program has been developed to deal with the largely male deportees from Malaysia (Lindquist 2013).

Most striking in the process of infrastructural involution, however, is the rise of the unlicensed petugas lapangan, meaning field agent, or PL for short, who recruits and deliver migrants to licensed agencies — akin to the Chinese "legs" described above — and in an important sense has replaced the tai kong of the earlier era. Although in some cases former tai kong have become PL, the primary differences between the two are that while tai kong escorted undocumented migrants across great distances, PL work within a more constricted space, delivering migrants to local recruitment companies while dealing with government paperwork.

In order for a villager to become a migrant there is an extensive process of documentation. The language associated with documents - tembak, to shoot, or jalan tol, toll road, for instance - points to the extra costs involved in accessing documents quickly. The road metaphor is apt since the process of documentation entails that the PL escorts prospective migrants to government offices and spends time waiting for documents to be produced. Great distances, bad roads, and lack of public transportation make mobility arduous and expensive in many areas. This means that transport, money, food, cigarrettes, and cell phone credit must be in good supply for the PL.

\footnotetext{
25 This is, for instance, the case with regard to government directives associated with Jakarta airport migrant reception terminal (Kloppenburg 2013).
} 
In contexts in which physical infrastructures are lacking or inadequate, PL are located at the heart of a "flexible configuration," what Simone calls "people as infrastructure" (2004: 410-1), which set migrants in motion through escort. Despite the ubiquity of cell phones and the fact that most migrants now travel directly by airplane rather than overland, it is the movement of migrants to the recruitment company on the provincial level that is the main logistical problem; thus in the space between villages and urban areas different forms of brokers and sub-brokers temporarily collaborate to move migrants to the recruitment company prior to departure. In this process, PL—particularly those who are most successful and considered reliable by recruitment companies - are able to control capital, documents, and the migrants themselves, generally without having direct access to foreign markets. As in the case of the Chinese "legs" much of this power is based on relations of trust with prospective migrants.

The regulation of the PL is at the center of current regulatory reforms. Since 2012, BNP2TKI in collaboration with APJATI, the Indonesian Manpower Services Association (Asosiasi Jasa Tenaga Kerja Indonesia), the national organization for licensed recruitment companies, has initiated a government-controlled licensing system for PL, who are to be registered in a database using biometric technology, in effect a radical attempt to formalize the informal. While previously PL were able to control migrants and corresponding documents until departure, thus allowing them to move migrants between recruitment companies, the licensing program connects prospective migrants to a specific PL at the regency level. This ideally allows recruitment companies and government agencies to regain control over the recruitment process and profits. More generally, this is part of BNP2TKI's broader attempt to create a migrant labor database based on biometric technology in an ongoing shift to e-governance. Although the actual effects of these changes are as yet unclear, they signal a further step in the process of infrastructural involution. 
The Chinese and the Indonesian cases represent two trajectories of infrastructural involution. In China both regulatory and commercial infrastructures have expanded outward and downward, from the center to the periphery, from Beijing to localities. In Indonesia, the involution partly manifests itself through the incorporation of previously existing social networks and informal brokers into the formal commercial and regulatory infrastructure, as well as humanitarian infrastructure that controls the mobility of migrants. What the two cases share in common is the mutually reinforcing relation between different dimensions of migration infrastructure.

In both cases, infrastructural involution is also manifested through the spatial concentration of the mediation processes in the sending countries and especially in the local areas of recruitment, as evidenced by the activities of the "legs" and PLs. The double-edged sword of "protection" further comes to intensify various forms of mediation. The main functions of migration infrastructure in Asian and Middle Eastern receiving countries in relation to unskilled migration are to confine the migrants to their employers, minimize their contacts with the local society and thus prevent settlement, and to enforce return particularly through repatriation (Xiang 2013). As such the migration infrastructure on the receiving side is considerably less elaborate than on the sending side.

\section{Conclusion}

Migration should not be imagined as a line between the two places, but rather as a multifaceted space. Occupied by commercial recruitment intermediaries, large and small, formal and informal, as well as bureaucrats, NGOs, and migrants, this is a space of mediation. In this space migration acquires its particular forms and meanings. This article argues that in the 
contemporary era this space has become larger and more complicated, involving more actors, activities, procedures, and resources.

The notion of migration infrastructure aims to unpack this space and place its internal workings in sharp relief. Migration infrastructure does not introduce new subjects of study, but calls for a new way of seeing and thinking about what has always been apparent. Thinking infrastructurally is to think simultaneously at two levels. First, we need to think of migration in terms of quotidian and processual operations: how, for instance, a form is designed, handed out, filled out by whom on whose behalf, how it travels, and comes to shape migration and its relation to other dimensions of social life. Migration is not determined by autonomous markets, policy logic, or according to individual migrant agency, but is rather constituted by a multitude of activities and practices that must be considered in specific contexts. Migration infrastructure provides a framework that offers analytical order to these activities without assigning them to pre-given categories. Second, we need to think relationally across the commercial, the regulatory, the social, the humanitarian, and the technological. Infrastructural involution - the intensification of migration infrastructure that does expand migrants' migratory capacities - is a specific example of how the interplay between different aspects of migration infrastructure becomes a central force in conditioning migration flows. This explains the phenomenon that unskilled labor has become both more accessible and more complicated in China and Indonesia. The emphasis on intersections across domains distinguishes migration infrastructure from the more conventional concepts of migration system, network, and industry. As such, migration infrastructure not only reveals how migration is constituted, but also turns migration into a powerful lens that sheds light on broader forms of societal change that are not strictly limited to migration, such as state-led market-oriented Chinese reform and post-Suharto economic and political transformation in Indonesia. 


\section{$\underline{\text { References }}$}

Agustín, Laura. 2007. Sex at the Margins: Migration, Labour Markets and the Rescue Industry. London: Zed Books.

Anderson, Ruben. 2014. "Hunter and Prey: Patrolling Clandestine Migration in the EuroAfrican Borderlands." Anthropological Quarterly 87(1):119-49.

Arango, Joaquín. 2004. Theories of International Migration. In D. Joly (ed.), International Migration and the New Millennium. Aldershot: Ashgate, 15-36.

Belanger, Daniele and Hong-zen Wang. 2013. "Becoming a Migrant: Vietnamese Emigration to East Asia." Pacific Affairs 86:31-50.

Bornstein, Erica and Peter Redfield. 2011. “An Introduction to the Anthropology of Humanitarianism.” In Forces of Compassion: Humanitarinism Between Ethics and Politics, edited by Erica Bornstein and Peter Redfield, 3-30. Santa Fe: School for Advanced Research Press.

Bureau of Labor and Social Security, Liaoning province. 2005. "Chart of the Conditions of the Personnel Employed Overseas and in Hong Kong and Macau" (Zai Guowai, Gang'ao Jiuye Renyuan Qingkuang Biao). (January to June 2005) Unpublished document.

Center for International Exchanges, Ministry of Labour and Social Security. 2008. "Jingwai Jieye Jiben Qingkuang” (“The Basic Facts of Overseas Employment”) Beijing: Center for International Exchanges. (unpublished report)

Chen Qinlan. 2008. Woguo duiwai laowu shuchu shichang fenxi yu duice yanjiu [A market analysis and policy study on China's international labor exports]. Jinrong Jingji [Finance and Economy]. No.3: 31-32.

CHICA (China International Contractor Association). 2004 -2012. Annual Reports on International Labor Cooperation. Beijing: China International Contractor Association.

Chin, Christine. 2008. “'Diversification' and 'Privatisation': Securing Insecurities in the Receiving Country of Malaysia.” Asia Pacific Journal of Anthropology 9: 285-303.

China Education Online. 2014. 2014 Report on Trends of Student Emigration. http://www.eol.cn/html/lx/2014baogao/ last accessed June 26, 2014.

Crenshaw, Kimberle. 1991. "Mapping the Margins: Intersectionality, Identity Politics, and Violence against Women of Color." Stanford Law Review 43(6):1241-1299. 
Duara, Prasenjit. 1987. "State Involution: A Study of Local Finances in North China, 19111935." Comparative Studies in Society and History 29(1):132-61.

Duara, Prasenjit. 1988. Culture, Power, and the State Rural North China, 1900-1942. Palo: Alto: Stanford University Press.

Feldman, Gregory. 2011. The Migration Apparatus. Palo Alto: Stanford University Press.

Frantz, Elizabeth. 2011. “Exporting Subservience: Sri Lankan Women’s Migration for Domestic Work in Jordan.” Ph.D. dissertation, Department of Anthropology, London School of Economics.

Gardner, Andrew. 2010. "Engulfed: Indian Guest Workers, Bahraini Citizens, and the Structural Violence of the Kafala System." In The Deportation Regime: Sovereignty, Space, and the Freedom of Movement, edited by Nicholas de Genova and Nathalie Peutz. Durham: Duke University Press.

Geertz, Clifford. 1963. Agricultural Involution: The Process of Ecological Change in Indonesia. Berkeley: University of California Press.

Global Commission of International Migration (GCIM). 2005. "Migration in an Interconnected World: New Directions for Action.” Report of the Global Commission on International Migration, 5. available at: http://www.refworld.org/docid/435f81814.html [accessed 15 May 2014].

Gold, Steven. 2005. "Migrant Networks: A Summary and Critique of Relational Approaches to International Migration.” In The Blackwell Companion to Social Inequalities, edited by in Mary Romero and Eric Margolis, 257-85. London: Blackwell.

Goss Jon and Bruce Lindquist. 1995. "Placing Movers: An Overview of Asian-Pacific Migration System." The Contemporary Pacific 12(2):385-414.

Goss Jon and Bruce Lindquist. 2000. "Conceptualizing International Labor Migration: A Structuration Perspective.” International Migration Review 29(2):317-351. Hamashita, Takeshi. 2008. China, East Asia and the Global Economy: Regional and Historical Perspectives, edited by Linda Grove and Mark Selden. New York Routledge.

Hannam, Kevin, Mimi Sheller, and John Urry. 2006. "Editorial: Mobilities, Immobilities and Moorings." Mobilities 1(1):1-22.

Hardt, Michael and Antonio Negeri. 2000. Empire. Cambridge: Harvard University Press. Hernández-Coss, Raúl, Gillian Brown, Chitawati Buchori, Isaku Endo, Emiko Todoroki, Tita Naovalitha, Wameek Noor and Cynthia Mar. 2008. "The Malaysia-Indonesia 
Remittance Corridor: Making Formal Transfers the Best Options for Women and Undocumented Migrants.” World Bank Working Paper 149.

Hernández-Léon, Ruben. 2008. Metropolitan Migrants: The Migration of Urban Mexicans to the United States. Berkeley: University of California Press.

Huang, Philip. 1985. The Peasant Economy and Social Change in North China. Stanford, California: Stanford University Press.

Hugo, Graeme. 2009. "Best Practice in Temporary Labour Migration for Development: Perspective from Asia and the Pacific." International Migration 47(5):23-74.

Hugo, Graeme. 2012. "International Labour Migration and Migration Policies in Southeast Asia.” Asian Journal of Social Science 40:392-418.

International Labour Organization. 2006. Realizing Decent Work in Asia: Fourteenth Asian Regional Migration Meeting: Report of the Director-General. Geneva: ILO.

International Organzation for Migration. 2013. The World Migration Report 2013: Migrant Well-being and Development. Geneva: IOM.

Jones, Sidney. 2000. Making Money off Migrants: The Indonesian Exodus to Malaysia. Hong Kong: Asia 2000.

Keck, Margaret and Kathryn Sikkink. 1998. Activists Beyond Borders: Advocacy Networks in International Politics. Ithaca: Cornell University Press.

Killias, Olivia. "Follow the Maid: A Multi-Sited Ethnography of Domestic Worker Migration from Indonesia.” Ph.D. dissertation, University of Bern, Switzerland.

King, Russell. 2002. “Towards a New Map of European Migration.” International Journal of Population Geography 8:89-106.

Kloppenburg, Sanneke. 2013. “Tracing Mobilities Regimes: The Regulation of Drug Smuggling and Labour Migration at Two Airports in the Netherlands and Indonesia." $\mathrm{PhD}$ diss., University of Amsterdam.

Kritz, Mary, Lin Lean Lim, and Hania Zlotnik. 1992. International Migration Systems: A Global Approach. Oxford: Clarendon Press.

Kuptsch, Christiane. 2006. “Introductory Overview.” In Merchants of Labor, edited by Christiane Kuptsch. Geneva: International Labour Organization (International Institute for Labour Studies). 
Larkin, Brian. 2012. "The Politics and Poetics of Infrastructure.” Annual Review of Anthropology 42(1):327-43.

Latour, Bruno. 1999. Pandora's Hope: Essays on the Reality of Science Studies. Cambridge, MA; London, UK: Harvard University Press.

Lindquist, Johan, Biao Xiang, and Brenda S. A. Yeoh. 2012. "Opening the Black Box of Migration: Brokers, the Organization of Transnational Mobility and the Changing Political Economy in Asia." Pacific Affairs 85(1):7-19.

Lindquist, Johan. 2010a. "Labour Recruitment, Circuits of Capital and Gendered Mobility: Reconceptualizing the Indonesian Migration Industry." Pacific Affairs 83(1): 115-132. Lindquist, Johan. 2010b. "Images and Evidence: Human Trafficking, Auditing, and the Production of Illicit Markets in Southeast Asia and Beyond.” Public Culture 22(2):223-36.

Lindquist, Johan. 2012. "The Elementary School Teacher, the Thug and His Grandmother: Informal Brokers and Transnational Migration From Indonesia.” Pacific Affairs 85(1):69-89.

Lindquist, Johan. 2013. "Rescue, Return, In Place: Deportees, Victims, and the Regulation of Indonesian Migration.” In Return: Nationalizing Transnational Mobility in Asia, edited by Xiang Biao, Brenda Yeoh, and Mika Toyota. Durham: Duke University Press, pp. 122-140.

Lyon, David. 2008. "Biometrics, Identification and Surveillance.” Bioethics 22(9):499-508. Mabogunje, Akin. 1970. "Systems Approach to a Theory of Rural-Urban Migration." Geographical Analysis 2(1):1-18.

Madianou, Mirca and Daniel Miller. 2011. Migration and New Media: Transnational Families and Polymedia. New York: Routledge.

Mann, Michael. 1984. "The Autonomous Power of the State: Its Origins, Mechanisms, and Results." Archives européenes de sociologie 25:85-213.

Martin, Philip. 2005. "Merchants of Labor: Agents of the Evolving Migration Infrastructure." Discussion Paper, DP/158/2005. Geneva: International Labour Organization (International Institute for Labour Studies).

Massey, Douglas. 1990. "Social Structure, Household Strategies, and the Cumulative Causation of Migration." Population Index 56:3-26. 
McLagan, Meg. 2003. "Human Rights, Testimony, and Transnational Publicity.” Scholar and Feminist Online 2(1), http://sfonline.barnard.edu/ps/mclagan.htm, accessed May 15, 2014.

Minister of Labor and Social Security, Ministry of Public Security, State Administration for Industry and Commerce. 2002. "Regulations on Overseas Employment Intermediaries", Decree 15, May14.

Ministry of Commerce. 2014. Brief statistics on China's foreign labor service cooperation condensed 2013. Released on 17 January. http://big5.mofcom.gov.cn/gate/big5/fec.mofcom.gov.cn/article/tjzl/lwhz/201401/1796 137_1.html, accessed June 25, 2014

Ministry of Labor and Social Security, Center for International Exchanges. 2005. "Basic Facts and Analyses of the Survey on Overseas Employment of 2004" (Jingwai Jieye Tongji Gongzuo Jiben Qingkuang yu Fenxi). Unpublished report.

Rodriguez, Robyn. 2010. Migrants for Export: How the Philippine State Brokers Labor to the World. Minneapolis: University of Minnesota Press.

Rudnyckyj, Daromir. 2004. "Technologies of Servitude: Governmentality and Indonesian Transnational Labor Migration.” Anthropological Quarterly 77(3):407-34.

Silvey, Rachel. 2007. “Unequal Borders: Indonesian Transnational Migrants at Immigration Control." Geopolitics 12(2):265-79.

Simone, AbdouMaliq. 2004. "People as Infrastructure: Intersecting Fragments in Johannesburg." Public Culture 16(3): 407-29.

Sørensen, Ninna Nyberg and Thomas Gammeltoft-Hansen. 2013. "Introduction.” In The Migration Industry and the Commercialization of International Migration, edited by Ninna Nyberg Sørensen and Thomas Gammeltoft-Hansen. London: Routledge.

Spaan, Ernst. 1994. "Taikongs and Calos: the Role of Middlemen and Brokers in Javanese International Migration.” International Migration Review 28(1):93-113.

Spaan, Ernst. 1999. Labour Circulation and Socioeconomic Tranformation: The Case of East Java, Indonesia. The Hague: Netherlands Interdisciplinary Demographic Institute, report no. 56.

Star, Susan Leigh. 1999. "The Ethnography of Infrastructure.” American Behavioral Scientist 43(3):377-91.

State Council, People's Republic of China. 2012. Regulation on the Administration of Foreign Labor Cooperation. No. 620. 4 June. 
Tilly, Charles. 1990. “Transplanted Networks." In Immigration Reconsidered: History, Sociology and Politics, edited by Virgina Yans-McLaughlin, 79-95. New York: Oxford University Press.

UN Department of Economic and Social Affairs. 2013. "Changing Landscape of International Policies.” Population Facts No. 2013/5.

UN Secretary General 2006. Report of the Secretary-General: International migration and development. New York: UN General Assembly. http://www.un.org/esa/population/migration/hld/Text/Report\%20of\%20the\%20SG(Jun e\%2006)_English.pdf, last accessed on 15 May 2014.

Urry, John. 2007. Mobilities. Cambridge: Polity Press. Chapter 1: 1-16.

Wen Yue, 2013, "2012 nian zhongguo duiwai laowu hzuo fazhan shuping” [Summaries and comments on China's international labor service for 2012]. Guoji Gongchen yu Laowu. [International Project Contracting and Labour Service]. Issue 3: 8-11.

Xia Hong. 2012. Guoji laowu hezuo yewu de xianzhuang yutupo. [The current state and possible breakthroughs in the business of international labor cooperation]. Jiangsu Jiancai [Jiangsu Construction Materials] No.11: 51-52.

Xiang Biao. 2013. Transnational Encapsulation: Compulsory Return as a Labor Migration Control in East Asia In Return: Nationalizing Transnational Mobility in Asia. Xiang Biao, Brenda Yeoh and Mika Toyota eds. Duke University Press. 83-99.

Yin Hao. 2009. A Study on the Development of China's International Labor Cooperation Since the Reform and Opening Up. Population Journal 1:27-30.

Zhang Gesheng. 1999. International Labor Economy. Chongqing: Chongqing University Press. 